\title{
RETRACTED ARTICLE: Influence of local and regional sources on the observed variability in the concentration levels of fine and coarse atmospheric aerosol water-soluble species in Athens
}

\section{Panagiotis Razos • Konstantinos Eleftheriadis}

Received: 5 August 2010 / Accepted: 16 March 2011 / Published online: 6 April 2011

(C) Springer Science+Business Media B.V. 2011

This article has been published OnlineFirst, but is retracted at the request of the authors.

This article has been published OnlineFirst, but is retracted at the request of the authors.

P. Razos $(\bowtie)$

Laboratory of Inorganic and Analytical Chemistry, Department of Chemical Engineering, National

Technical University of Athens, Iroon Polytechniou 9, 15773 Athens, Greece

e-mail: razouli@otenet.gr

K. Eleftheriadis

National Center for Scientific Research Demokritos, Institute of Nuclear Technology-Radiation Protection, Environmental Radioactivity Lab, N.C.S.R

"Demokritos", Agia Paraskevi, 15310 Athens, Greece 